DOI: $10.17957 / \mathrm{IJAB} / 15.1883$

http://www.fspublishers.org

\title{
Heterologous Expression of chi42 Gene from Trichoderma asperellum in Bacillus subtilis
}

\author{
Nguyen Hoang Tue ${ }^{1}$, Trinh Thi My Uyen', Hoang Anh Thi', Nguyen Hoang Minh², Tran Gia Cat Tuong², Ngo Thi \\ Minh Thu ${ }^{3}$, Nguyen Duc Chung ${ }^{4}$ and Nguyen Hoang Loc ${ }^{1^{*}}$ \\ ${ }^{1}$ Institute of Bioactive Compounds, University of Sciences, Hue University, Hue, Vietnam \\ ${ }^{2}$ University of Medicine and Pharmacy, Hue University, Hue, Vietnam \\ ${ }^{3}$ Duy Tan University, Da Nang, Vietnam \\ ${ }^{4}$ University of Agriculture and Forestry, Hue University, Hue, Vietnam \\ *For correspondence: nhloc@hueuni.edu.vn
}

Received 04 June 2021; Accepted 09 October 2021; Published 16 December 2021

\begin{abstract}
Chitinase is the enzyme that hydrolyzes chitin, a major component of fungal cell walls. This enzyme has the potential to be applied against certain phytopathogenic fungi for fruit preservation. Therefore, this study aimed to produce the extracellular 42 kDa chitinase of $T$. asperellum SH16 in B. subtilis BD170 (rCHI42) and evaluate preliminary its antifungal activity as the basis for further applications. The results showed that the chitinase activity of rCHI42 peaked at $27 \mathrm{U} / \mathrm{mL}$ after $8 \mathrm{~h}$ of Bacillus induction with $4 \mathrm{~m} M$ IPTG. The investigation revealed that $\mathrm{rCHI} 42$ had the optimum $\mathrm{pH}$ and temperature of 7 and $45^{\circ} \mathrm{C}$, the $\mathrm{pH}$ and thermal stability were in the range of $6-8$ and $25-35^{\circ} \mathrm{C}$, respectively. Some metal ions $\left(\mathrm{Fe}^{2+}, \mathrm{Al}^{3+}, \mathrm{Ca}^{2+}, \mathrm{and}^{2+}\right)$ increased the relative activity of rCHI42 from 109 to $148 \%$, while the enzyme was inhibited by most of the tested reagents (SDS, EDTA, urea, Triton X-100, and DMSO). rCHI42 also exhibited antifungal ability against phytopathogenic fungus Aspergillus niger which contains chitin in its cell wall. (C) 2021 Friends Science Publishers
\end{abstract}

Keywords: 42 kDa chitinase; Bacillus subtilis; chi42, heterologous expression; Trichoderma asperellum

\section{Introduction}

Chitinase (EC 3.2.1.14), whose molecular weight ranges from $20 \mathrm{kDa}$ to about $90 \mathrm{kDa}$, is an enzyme group that hydrolyzes glycosidic linkages in chitin molecule to form oligosaccharides which will be further degraded by $\beta-\mathrm{N}$ acetylhexosaminidase (EC 3.2.1.52) to $\mathrm{N}$ acetylglucosamine (GlcNAc) (Hamid et al. 2013). Chitin is a primary component of cell walls in fungi, the exoskeletons of arthropods and the radula of mollusks (Jones et al. 2020). Chitinases were found in fungi, yeasts, actinomycetes, bacteria, plants, arthropods and mammals (Kumar et al. 2018). Many have been characterized, mostly from plants and bacteria and in minor proportion from fungi because of the important applications of chitinases in the fields of agriculture, pharmacy, food industry and pollution abatement (Nagpure et al. 2014; Rathore and Gupta 2015).

Most chitinase genes were cloned and heterologously expressed in E. coli hosts such as Chi58 from Sanguibacter spp. C4 (Tao et al. 2006), endochitinase gene from $B$. cereus (Chen et al. 2009), ChiA from B. licheniformis DSM8785 (Songsiriritthigul et al. 2010), Ifu-chit2 from
Isaria fumosorosea (Meng et al. 2015), ChiKJ406136 from Streptomyces sampsonii (Li et al. 2018) and Chi from Paenibacillus chitinolyticus UMBR 0002 (Liu et al. 2020). However, some other microorganisms have also been used as suitable hosts for this enzyme, e.g., B. thuringiensis for chiA gene of Serratia marcescens (Okay et al. 2008), yeast Saccharomyces cerevisiae for chitinase gene of Thermomyces lanuginosus (Prasad and Palanivelu 2012), yeast Pichia pastoris for ScCTS1 gene of S. cerevisiae (Youxi et al. 2015).

Although B. subtilis has become an increasingly popular host for recombinant protein expression due to its ability to directly secrete protein into culture media, it is amenable to medium- and large-scale fermentation, lack of codon bias and designation as a safe organism (FDA 2018). To date, only a few studies produced foreign chitinase in $B$. subtilis such as the chitinase derived from B. pumilus (Ahmadian et al. 2012) and chitinase A from $S$. marcescens (Okay and Alshehri 2020). This study reports on the expression of the $42 \mathrm{kDa}$ chitinase (GH family 18 ) from $T$. asperellum SH16 in $B$. subtilis BD170 and its characterizations and antifungal activity. 


\section{Materials and Methods}

\section{Cloning chi42 gene}

The chi42 gene (NCBI: HM191683) was isolated from genomic DNA of T. asperellum SH16 by PCR amplification with specific primers as described in our previous report (Loc et al. 2011) containing two overhangs of XmaI and BamHI and then cloned in pGEM-T Easy vector (Promega). The recombinant cloning vector was cut at XmaI and BamHI sites to insert the chi42 gene into the same site downstream of the Pgrac promoter and the SP amyQ signal peptide of pHT43 Bacillus expression vector (MoBiTec). Finally, the pHT43/chi42 vector was transformed into $B$. subtilis BD170 cells by the chemical method according to Vojcic et al. (2012). Restriction digestion and PCR amplification were performed to determine the presence of the chi42 gene in transformed cells.

\section{Expression of chi42 gene}

BD170 cells containing vector pHT43/chi42 were grown in Luria-Bertani (LB) broth at a shaking speed of $180 \mathrm{rpm}$ at $37^{\circ} \mathrm{C}$ overnight. After dilution to an $\mathrm{OD}_{600}$ of 0.15 using LB broth, the culture was continued until $\mathrm{OD}_{600}$ reaching a value of 0.7 to 0.8 . Four millimoles of isopropyl $\beta$-d-1thiogalactopyranoside (IPTG) were then added to the culture and the mixture was incubated at $37^{\circ} \mathrm{C}$ for $2-10 \mathrm{~h}$ to induce chi42 expression. The supernatant from induction culture containing the recombinant $42 \mathrm{kDa}$ chitinase (rCHI42) was harvested every $2 \mathrm{~h}$. The crude enzyme from the supernatant was partially purified by precipitation of neutral salt to use for further studies. The precipitation was carried out at $4^{\circ} \mathrm{C}$ for $2 \mathrm{~h}$ in stirring conditions using $70 \%$ saturation ammonium sulfate. Centrifugation at 15,000 rpm at $4^{\circ} \mathrm{C}$ for $10 \mathrm{~min}$ was performed to recover the pellet which was then re-suspended in $0.1 \mathrm{M}$ sodium acetate buffer $(\mathrm{pH}$ 5) and dialyzed with $12 \mathrm{kDa}$ molecular weight cut-off membrane overnight against the same buffer. The expression of the chi42 gene was determined by sodium dodecyl sulfate-polyacrylamide gel electrophoresis (SDSPAGE) and stained with Coomassie Blue R-250.

Zymography of rCHI42 was carried out according to Berini et al. (2017) with a slight modification using $12 \%$ $(w / v)$ polyacrylamide gels containing $0.7 \mathrm{mg} / \mathrm{mL}$ of carboxymethyl-chitin-remazol brilliant violet. The mixture of enzyme and loading buffer was incubated at room temperature (RT) for $10 \mathrm{~min}$. Electrophoresis was then performed at $4{ }^{\circ} \mathrm{C}$ in the Tris-glycine-SDS buffer. The gel was washed twice in $2.5 \%(v / v)$ Triton $\mathrm{X}-100$ for $30 \mathrm{~min}$ at RT to remove SDS and incubated in $50 \mathrm{~m} M$ acetate buffer $\left(\mathrm{pH} \mathrm{6)}\right.$ at $37^{\circ} \mathrm{C}$ until the clear zones of the chitinolytic activity were observed.

\section{Assay for chitinase activity}

The agar plate method with $1.2 \%(w / v)$ colloidal chitin as the substrate was used for the assay of the chitinolytic activity of rCHI42. $10 \mathrm{U}$ enzyme was loaded into prepunched holes in agar plate and kept at $28^{\circ} \mathrm{C}$ for $6 \mathrm{~h}$, then stained with $0.1 \%$ Lugol solution to detect substrate hydrolysis. Chitinase activity of rCHI42 was determined by the measurement of the absorbance of the hydrolyzed product at $420 \mathrm{~nm}$ with $p$ NP-GlcNAc as a substrate (Tsujibo et al. 1998). $70 \mu \mathrm{L}$ rCHI42 was added to $140 \mu \mathrm{L}$ of substrate solution at a concentration of $2.5 \mathrm{mM}(\mathrm{pH} 6)$ and left at $50^{\circ} \mathrm{C}$ for $10 \mathrm{~min}$. The reaction was then stopped with $0.2 \mathrm{M}$ sodium carbonate. The chitinase activity of $\mathrm{rCHI} 42$ is defined as the amount of enzyme required to release $1 \mu \mathrm{mol}$ of $p$-nitrophenol from the substrate within one minute. The $p$-nitrophenol standard was purchased from Sigma-Aldrich.

\section{Characterization of $\mathrm{rCHI42}$}

The optimum temperature and $\mathrm{pH}$ of rCHI42 were investigated in the ranges of $30-70^{\circ} \mathrm{C}$ and $4-10$, respectively. Buffers such as $20 \mathrm{~m} M$ citrate solution (pH 46), $20 \mathrm{~m} M$ phosphate solution ( $\mathrm{pH} 7-8$ ) and $20 \mathrm{~m} M$ glycinesodium hydroxide solution ( $\mathrm{pH} 9-10)$ were used to find the optimum $\mathrm{pH}$. The enzyme was incubated at $25-70^{\circ} \mathrm{C}$ and $\mathrm{pH} \mathrm{4-10} \mathrm{without} \mathrm{substrate} \mathrm{for} 30 \mathrm{~min}$ to determine their thermal and $\mathrm{pH}$ stability.

$5 \mathrm{~m} M$ of metal ions $\left(\mathrm{Na}^{+}, \mathrm{Al}^{3+}, \mathrm{Fe}^{2+}, \mathrm{Mg}^{2+}, \mathrm{Cu}^{2+}, \mathrm{Co}^{2+}\right.$, $\mathrm{Ca}^{2+}, \mathrm{Zn}^{2+}, \mathrm{Mn}^{2+}$ and $\mathrm{Fe}^{3+}$ ) or different concentrations of reagents (1 $\mathrm{M}$ urea, $1 \%$ sodium dodecyl sulfate (SDS), 1 $\mathrm{m} M$ ethylenediaminetetraacetic acid (EDTA), 5\% dimethyl sulfoxide (DMSO), and 1\% Triton X-100) was added to rCHI42 solution and kept at $35^{\circ} \mathrm{C}$ and $\mathrm{pH} 7$ for $30 \mathrm{~min}$ to evaluate their effect on the enzyme activity. The relative activity (\%) of rCHI42 is the percentage ratio of the enzyme activity with treatment and without treatment (control).

\section{Antifungal activity of rCHI42}

The antifungal activity of rCHI42 was preliminarily tested using fungus $A$. niger, a type of black mold that causes disease in plants. A test based on inhibition of mycelial growth of $A$. niger was carried out to determine in vitro antifungal activity of rCHI42. $60 \mathrm{U} / \mathrm{mL}$ rCHI42 and $10 \mu \mathrm{L}$ of fungal spore suspension (about $10^{6}$ spores $/ \mathrm{mL}$ ) were added to a Petri dish containing $1 / 2$ potato dextrose agar medium and incubated at $28^{\circ} \mathrm{C}$ for $48 \mathrm{~h}$ to evaluate the inhibitory effect of the enzyme.

Healthy mango fruits were washed under running water, followed by treatment with $70 \%$ ethanol, finally washed again with sterile deionized water. Each mango fruit was sprayed with $1 \mathrm{~mL}$ rCHI42 (60 U), then allowed to dry naturally and artificially inoculated with about $10^{4}$ fungal spores/lesion, 6 lesions/fruit. After treatment, mangoes were left in boxes and kept at RT to track the disease progression.

\section{Statistics}

All treatments were repeated three times. Data on the activity of $\mathrm{rCHI} 42$ were expressed as the means \pm SEs, followed by an analysis of variance with Duncan's test ( $P$ at 0.05 level). 


\section{Results}

\section{Expression of chi42 gene}

The chi42 gene from T. asperellum SH16 was isolated by PCR amplification, then inserted into the pHT43 vector and finally transformed into BD170 cells. The presence of the pHT43/chi42 vector was determined by digestion of BamHI and PCR amplification to produce a linearized DNA fragment of about $9.5 \mathrm{~kb}$ (pHT43 vector of $8 \mathrm{~kb}$ long and chi42 gene of $1.5 \mathrm{~kb}$ long) and a PCR product of about $1.5 \mathrm{~kb}$ (chi42 gene), respectively, as expected. A DNA band of uncut pHT43/chi42 vector as control located at a lower site of about $7 \mathrm{~kb}$ on the agarose gel compared to that digested by BamHI (Fig. 1).

Expression of rCHI42 was determined by SDS-PAGE. A protein band predicted as rCHI42 with estimated molecular weight of approximately $42 \mathrm{kDa}$ (mature protein) was found on the gel (Fig. 2A). A signal peptide of about $4 \mathrm{kDa}$ of the full-length chitinase molecule of $\sim 46 \mathrm{kDa}$, corresponding to chi42 gen of about $1.5 \mathrm{~kb}$, could have been cleaved from the rCHI42 after this enzyme was secreted outside the cell (Carsolio et al. 1994). The zymogram also showed a clear zone on the gel that has the same size as the target protein band in SDS-PAGE (Fig. 2B). Chitinase activity of partially purified rCHI42 from bacterial culture peaked at about 27 $\mathrm{U} / \mathrm{mL}$ after $8 \mathrm{~h}$ of induction with $4 \mathrm{~m} M$ IPTG (Fig. 2C). However, in another observation, chitinase activity from parental B. subtilis BD170 used as control was not found.

Five transformed BD170 cell colonies (clones) selected to test the chitinolytic activity of their rCHI42 on colloidal chitin-containing agar plates. The largest $D-d$ of about $1.5 \mathrm{~cm}$ was found in the $\mathrm{C}-1$ clone, while the hydrolysis was not present in the control (Fig. 2D). In which, $D$ and $d$ are the diameters of the hydrolysis zone and the pre-punched hole, respectively.

\section{Characterization of $\mathrm{rCHI} 42$}

Fig. 3A and B show that the relative activity of rCHI42 peaked at $143 \%(\sim 38 \mathrm{U} / \mathrm{mL})$ at the optimum temperature and $\mathrm{pH}$ of $45^{\circ} \mathrm{C}$ and 7 , respectively. $\mathrm{rCHI} 42$ has thermal and $\mathrm{pH}$ stability in the range of $25-35^{\circ} \mathrm{C}$ and 6-8 with the relative activity being from $83-86 \%$ and $90-93 \%$, respectively.

In the tested metal ions, $\mathrm{Fe}^{2+}, \mathrm{Al}^{3}+, \mathrm{Ca}^{2+}$ and $\mathrm{Mn}^{2+}$ increased chitinolytic activity of rCHI42, among them $\mathrm{Mn}^{2+}$ had the highest effect, the relative activity of the enzyme reached $148 \%$. While other ions such as $\mathrm{Fe}^{3+}, \mathrm{Zn}^{2+}, \mathrm{Co}^{2+}$, $\mathrm{Mg}^{2+}, \mathrm{Cu}^{2+}$ and $\mathrm{Na}^{+}$were the opposite, of which $\mathrm{Zn}^{2+}$ had the strongest inhibitory effect, the enzyme has only $25 \%$ relative activity. The chitinolytic activity of rCHI 42 was inhibited by most reagents such as SDS, Triton X-100, EDTA, urea and DMSO. The relative activity of the enzyme reached the lowest value of approximately $11 \%$ when was treated with $1 \%$ SDS (Fig. 3C).

\section{Antifungal activity assay}

The study showed that rCHI42 at a concentration of 60

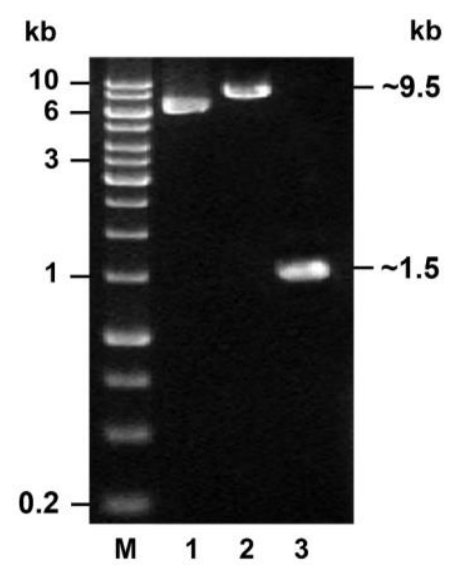

Fig. 1: Identification of pHT43/chi42 vector in transformed $B$. subtilis BD170 by BamHI digestion and PCR amplification. 1: uncut pHT43/chi42 vector as control, 2: pHT43/chi42 vector was linearized by BamHI, 3: PCR amplification of chi42 gene. M: DNA size marker (Thermo Scientific ${ }^{\mathrm{TM}}$ O'GeneRuler $1 \mathrm{~kb}$ DNA Ladder)
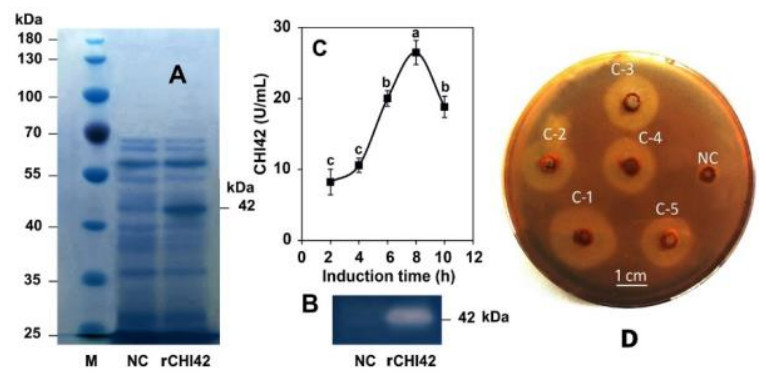

Fig. 2: (A) Expression analysis of rCHI42 in B. subtilis BD170 by SDS-PAGE, NC: parental B. subtilis BD170 as control, rCHI42: transformed B. subtilis BD170, M: protein weight marker (PageRuler $^{\mathrm{TM}}$ Prestained Protein Ladder, Thermo Fisher Scientific). (B) Zymogram of rCHI42. (C) A profile of chitinase activity in transformed $B$. subtilis BD170 after different induction times with $4 \mathrm{~m} M$ IPTG, different letters represent statistically significant differences based on Duncan's test $(P<0.05)$. (D) Chitinolytic activity of rCHI42 from various transformed BD170 cell clones ( $\mathrm{C}-1$ to $\mathrm{C}-5)$ on the agar plate containing colloidal chitin, NC: parental BD170 as control

$\mathrm{U} / \mathrm{mL}$ inhibited in vitro growth of fungus (Fig. 4A and 4B).

According to Krishnapillaim and Wijeratnam (2013), A. niger fungus has caused significant economic damage to mangoes in some regions in Sri Lanka and India. Our result also revealed that rCHI42 could inhibit the growth of $A$. niger in mango fruits. The fungus still did not appear on the mango after $96 \mathrm{~h}$ of enzyme treatment, while they grew quite strongly in the control (Fig. 4C and 4D).

\section{Discussion}

To date, only a few microbial chitinase genes have been successfully expressed on Bacillus hosts such as the chiA gene from S. marcescens (Okay et al. 2008; Okay and Alshehri 2020) or the chitinase gene from B. pumilus 

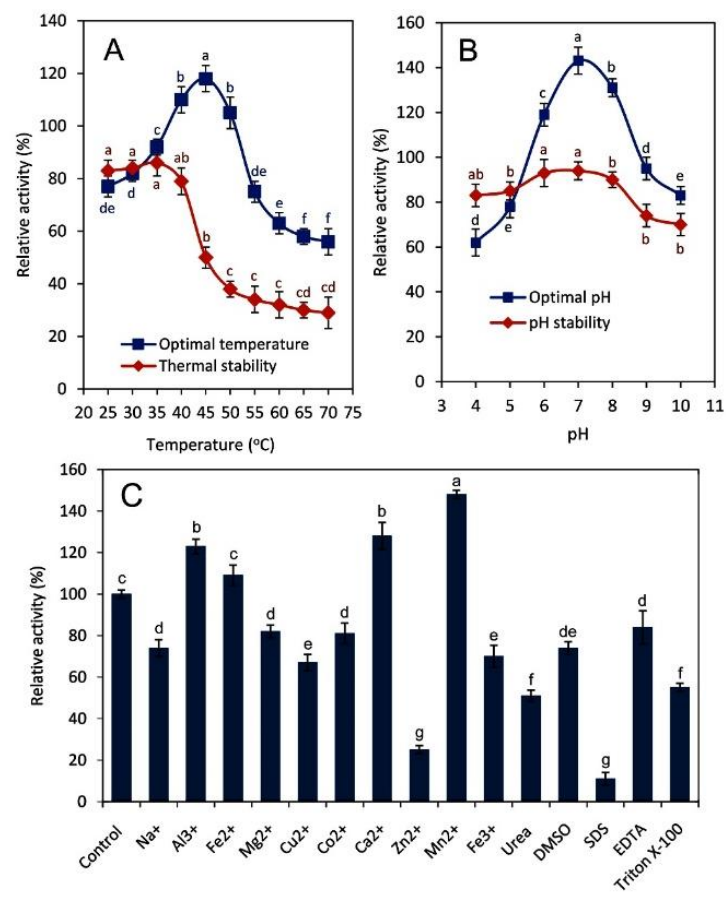

Fig. 3: Characterization of rCHI42 from transformed BD170 cells (C-1 clone). A, $\mathbf{B}$ and $\mathbf{C}$ : effect of temperature, $\mathrm{pH}$, and metal ions and reagents on enzyme activity. Different letters on a curve or columns represent statistically significant differences based on Duncan's test $(P<0.05)$

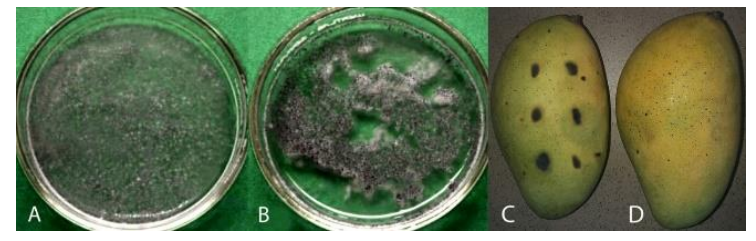

Fig. 4: Effect of rCHI42 on in vitro growth of A. niger - (A): medium without chitinase as control and $(\mathbf{B})$ : medium containing $60 \mathrm{U} / \mathrm{mL}$ of rCHI42. Effect of rCHI42 pre-treatment on mango after $96 \mathrm{~h}$ of $A$. niger infection - (C): control without $\mathrm{rCH} 42$, and (D): fruit with $60 \mathrm{U} / \mathrm{mL}$ rCHI42

(Ahmadian et al. 2012; Rostami et al. 2017). And most of them are promising sources for agricultural and biotechnological applications.

Several studies found different optimal temperatures of chitinase from Trichoderma species. The optimum temperature of $T$. viride chitinase was $50^{\circ} \mathrm{C}$ (Ekundayo et al. 2016) while Rao et al. (2016) found that the optimal temperature of chitinase from Trichoderma isolates was $30^{\circ} \mathrm{C}$. CHIT42 chitinase from T. harzianum displayed maximum activity at $35^{\circ} \mathrm{C}$ when expressed in yeast Pichia pastoris (Kidibule et al. 2018). Kapat and Panda (1997) showed that chitinase from $T$. harzianum has an optimum temperature of $24^{\circ} \mathrm{C}$ with thermal stability in the range of $50-60^{\circ} \mathrm{C}$. T. asperellum UTP-16 revealed the highest chitinase activity at $35^{\circ} \mathrm{C}$ (Kumar et al. 2012).
Generally, Trichoderma sp. can grow in a wide range of $\mathrm{pH}$, however, the optimum range was reported to be between 4.6 and 6.8 (Singh et al. 2014). Chitinase of T. viride had the highest activity at pH 5 (Ekundayo et al. 2016). A study by Kapat and Panda (1997) showed that optimal pH of chitinase from $T$. harzianum was 5.4 whereas the strain $T$. asperellum UTP-16 has the optimal pH at 6 (Kumar et al. 2012).

The inhibitory effect of metal ions such as $\mathrm{Fe}^{3+}, \mathrm{Zn}^{2+}$ and $\mathrm{Mg}^{2+}$ at a concentration of $5 \mathrm{~m} M$ was observed for chitinase of T. viride (Omumasaba et al. 2001). However, unlike rCHI42 derived from $T$. asperellum SH16 in this study, T. viride chitinase was inhibited by $\mathrm{Ca}^{2+}$ and $\mathrm{Mn}^{2+}$. Another study showed that the chitinase of $T$. viride was reduced in activity when was treated with $\mathrm{Zn}^{2+}, \mathrm{Mn}^{2+}$ and EDTA whereas $\mathrm{Ca}^{2+}$ maximized the enzyme activity (Ekundayo et al. 2016). However, the concentration to which the ions were used was not mentioned in this study.

Filamentous fungi Trichoderma spp. were considered as biocontrol agents against plant pathogenic fungi because they can produce chitinolytic enzymes. A study by Harighi et al. (2007) indicated that chitinase 42 from Trichoderma atroviride PTCC5220 inhibited the growth of Rhizoctonia solani, a plant pathogenic fungus. Mazrou et al. (2020) found the relationship between antagonistic activity of six Trichoderma harzianum strains against some plant pathogenic fungi such as Colletotrichum gossypii, Fusarium oxysporum, Fusarium fujikuroi, $R$. solani, Aspergillus calidoustus and Alternaria brassicicola and their chitinolytic enzyme production.

To date, many studies have reported the antifungal activity of Trichoderma spp. (Loc et al. 2020). However, it is difficult to find relevant studies in T. asperellum, especially their recombinant chitinase, except for the previous reports by Cruz-quiroz et al. (2018), Loc et al. (2020), Tien et al. (2021), Luong et al. (2021).

\section{Conclusion}

In conclusion, chi42 gene coding $42 \mathrm{kDa}$ chitinase of $T$. asperellum SH16 was successfully expressed in $B$. subtilis BD170. $42 \mathrm{kDa}$ chitinase is a neutral enzyme that was highly active at $45^{\circ} \mathrm{C}$ and inhibited the growth of A. niger.

\section{Acknowledgements}

This work was supported by National Foundation for Science and Technology Development (NAFOSTED), Vietnam (Grant number 106.02-2017.346).

\section{Author Contributions}

NH Tue: literature search, data collection, data analysis and interpretation. TTM Uyen, HA Thi, NH Minh, TGC Tuong, NTM Thu and ND Chung: data collection and data analysis. NH Loc: design of the work, performing the analysis, drafting the article, critical revision. All authors final approval of the version to be published. 


\section{Conflicts of Interest}

All authors declare no conflicts of interest

\section{Data Availability}

Data presented in this study will be available on a fair request to the corresponding author.

\section{Ethics Approval}

Not applicable in this paper.

\section{References}

Ahmadian G, M Keshavarz, MA Zeydabadi (2012). Cloning and expression of recombinant antifungal chitinase enzyme of Bacillus pumilus in Bacillus subtilis 168. Koomesh 13:151-158

Berini F, I Presti, F Beltrametti, M Pedroli, KM Vårum, L Pollegioni, S Sjöling, F Marinelli (2017). Production and characterization of a novel antifungal chitinase identified by functional screening of a suppressive-soil metagenome. Microb Cell Fact 16; Article 16

Carsolio C, A Gutiérrez, B Jiménez, MV Montagu, A Herrera-Estrella (1994). Characterization of ech-42, a Trichoderma harzianum endochitinase gene expressed during mycoparasitism. Proc Natl Acad Sci 91:10903-10907

Chen WM, GH Chen, CS Chen, ST Jiang (2009). Cloning, expression and purification of Bacillus cereus endochitinase in the Escherichia coli AD494(DE3) pLysS expression system. Biosci Biotechnol Biochem 73:1172-1174

Cruz-Quiroz RDL, S Roussos, R Rodríguez-Herrera, D Hernandez-Castillo, CN Aguilar (2018). Growth inhibition of Colletotrichum gloeosporioides and Phytophthora capsici by native Mexican Trichoderma strains. Karbala Intl J Mod Sci 4:237-243

Ekundayo EA, FO Ekundayo, F Bamidele (2016). Production, partial purification and optimization of a chitinase produced from Trichoderma viride, an isolate of maize cob. Mycosphere 7:786-793

FDA (2018). Available at: https://www.fda.gov/food/generally-recognizedsafe-gras/microorganisms-microbial-derived-ingredients-used-foodpartial-list (Accessed on 7 March 2021)

Hamid R, MA Khan, M Ahmad, MM Ahmad, MZ Abdin, J Musarrat, S Javed (2013). Chitinases: An update. J Pharm Bioallied Sci 5:21-29

Harighi MJ, MR Zamani, M Motallebi (2007). Evaluation of antifungal activity of purified chitinase 42 from Trichoderma atroviride PTCC5220. Biotechnology 6:28-33

Jones M, M Kujundzic, S John, A Bismarck (2020). Crab vs. mushroom: A review of crustacean and fungal chitin in wound treatment. Mar Drugs 18:64

Kapat A, I Panda (1997). pH and thermal stability studies of chitinase from Trichoderma harzianum: A thermodynamic consideration. Bioprocess Eng 16:269-272

Kidibule PE, P Santos-Moriano, E Jiménez-Ortega, M Ramírez-Escudero, MC Limón, M Remacha, FJ Plou, J Sanz-Aparicio, M Fernández-Lobato (2018). Use of chitin and chitosan to produce new chitooligosaccharides by chitinase Chit42: Enzymatic activity and structural basis of protein specificity. Microb Cell Fact 17; Article 47

Krishnapillaim N, RSW Wijeratnam (2013). Aspergillus rot of ripe mangoes (Mangifera indica L.) var. Ambalavi, Willard and Karuthakolumban. J Natl Sci Found Sri Lanka 41:69-70

Kumar DP, RK Singh, PD Anupama, MK Solanki, S Kumar, AK Srivastava, PK Singhal, DK Arora (2012). Studies on exo-chitinase production from Trichoderma asperellum UTP-16 and its characterization. Ind $J$ Microbiol 52:388-395

Kumar M, A Brar, M Yadav, A Chawade, V Vivekanand, N Pareek (2018). Chitinases - potential candidates for enhanced plant resistance towards fungal pathogens. Agriculture 8:8070088

Li S, B Zhang, H Zhu, T Zhu (2018). Cloning and expression of the chitinase encoded by ChiKJ406136 from Streptomyces sampsonii (Millard \& Burr) Waksman KJ40 and its antifungal effect. Forests 9; Article 699
Liu C, N Shen, J Wu, M Jiang, S Shi, J Wang, Y Wei, L Yang (2020). Cloning, expression and characterization of a chitinase from Paenibacillus chitinolyticus strain UMBR 0002. PeerJ 8; Article e8964

Loc NH, ND Huy, HT Quang, TT Lan, TTT Ha (2020). Characterisation and antifungal activity of extracellular chitinase from a biocontrol fungus, Trichoderma asperellum PQ34. Mycology 11:38-48

Loc NH, HT Quang, NB Hung, ND Huy, TTB Phuong, TTT Ha (2011). Trichoderma asperellum Chi42 genes encode chitinase. Mycobiology 39:182-186

Luong NN, NQD Tien, NX Huy, NH Tue, LQ Man, DDH Sinh, DV Thanh, DTK Chi, PTB Hoa, NH Loc (2021). Expression of $42 \mathrm{kDa}$ chitinase of Trichoderma asperellum (Ta-CHI42) from a synthetic gene in Escherichia coli. FEMS Microbiol Lett 368; Article 110

Mazrou YS, AH Makhlouf, MM Hassan, A Baazeem, AA Hamad, MM Farid (2020). Influence of chitinase production on the antagonistic activity of Trichoderma against plant-pathogenic fungi. J Environ Biol 41:1501-1510

Meng H, Z Wang, X Meng, L Xie, B Huang (2015). Cloning and expression analysis of the chitinase gene Ifu-chit 2 from Isaria fumosorosea. Genet Mol Biol 38:381-389

Nagpure A, B Choudhary, RK Gupta (2014). Chitinases: In agriculture and human healthcare. Crit Rev Biotechnol 34:215-232

Okay S, WA Alshehri (2020). Overexpression of chitinase A gene from Serratia marcescens in Bacillus subtilis and characterization of enhanced chitinolytic activity. Braz Arch Biol Technol 63:1-8

Okay S, BE Tefon, M Ozkan, G Ozcengiz (2008). Expression of chitinase A (chiA) gene from a local isolate of Serratia marcescens in Coleopteraspecific Bacillus thuringiensis. J Appl Microbiol 104:161-170

Omumasaba CA, N Yoshida, K Ogawa (2001). Purification and characterization of a chitinase from Trichoderma viride. J Gen Appl Microbiol 47:53-61

Prasad M, P Palanivelu (2012). Overexpression of a chitinase gene from the thermophilic fungus, Thermomyces lanuginosus in Saccharomyces cerevisiae and characterization of the recombinant chitinase. J Microb Biochem Technol 4:86-91

Rao KLNM, RK Siva, H Ravisankar (2016). Cultural conditions on the production of extracellular enzymes by Trichoderma isolates from tobacco rhizosphere. Braz J Microbiol 47:25-32

Rathore AS, RD Gupta (2015). Chitinases from bacteria to human: Properties, applications, and future perspectives. Enz Res 2015; Article 791907

Rostami A, K Hinc, F Goshadrou, A Shali, M Bayat, M Hassanzadeh, M Amanlou, N Eslahi, G Ahmadian (2017). Display of B. pumilus chitinase on the surface of $B$. subtilis spore as a potential biopesticide. Pest Biochem Physiol 140:17-23

Singh A, M Shahid, M Srivastava, S Pandey, A Sharma, V Kumar (2014). Optimal physical parameters for growth of Trichoderma species at varying $\mathrm{pH}$, temperature and agitation. Virol Mycol 3; Article 1000127

Songsiriritthigul C, S Lapboonrueng, P Pechsrichuang, P Pesatcha, M Yamabhai (2010). Expression and characterization of Bacillus licheniformis chitinase (ChiA), suitable for bioconversion of chitin waste. Bioresour Technol 101:4096-4103

Tao Y, H Jin, ZF Long, L Zhang, XQ Ding, K Tao, SG Liu (2006). Cloning and expression of a chitinase gene from Sanguibacter spp. C4. Acta Genet Sin 33:1037-1046

Tien NQD, PTB Hoa, NH Tue, DV Thanh, HA Thi, NN Luong, NX Huy, NH Loc (2021). Transient expression of Chi42 genes from Trichoderma asperellum in Nicotiana benthamiana by agroinfiltration. Intl J Agric Biol 26:177-184

Tsujibo H, N Hatano, T Mikami, A Hirasawa, K Miyamoto, Y Inamori (1998). A novel $\beta$-N-acetylglucosaminidase from Streptomyces thermoviolaceus OPC-520: Gene cloning, expression, and assignment to family 3 of the glycosyl hydrolases. Appl Environ Microbiol 64:2920-2924

Vojcic L, D Despotovic, R Martinez, KH Maurer, U Schwaneberg (2012). An efficient transformation method for Bacillus subtilis DB104. Appl Microbiol Biotechnol 94:487-493

Youxi Z, J Huihui, R Zhiming, J Yizhi, C Yanling, M Yanhe (2015). High level expression of Saccharomyces cerevisiae chitinase (ScCTS1) in Pichia pastoris for degrading chitin. Intl J Agric Biol Eng 8:142-150 